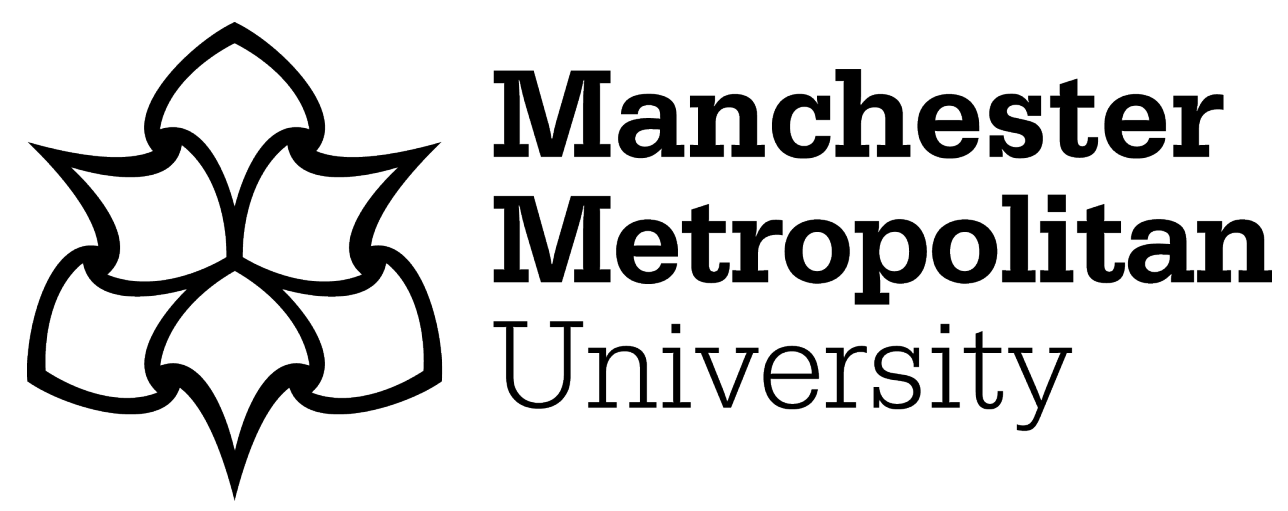

Oldfield, J ORCID logoORCID: https://orcid.org/0000-0002-7518-118X, Rodwell, J, Curry, L and Marks, G (2017) A face in a sea of faces: exploring university students' reasons for non-attendance to teaching sessions. Journal of Further and Higher Education, 43 (4). pp. 443-452. ISSN 0309-877X

Downloaded from: https://e-space.mmu.ac.uk/619008/

Version: Accepted Version

Publisher: Taylor \& Francis

DOI: https://doi.org/10.1080/0309877X.2017.1363387

Please cite the published version 


\section{A face in a sea of faces: exploring university students' reasons for non- attendance to teaching sessions.}

Jeremy Oldfield (j.oldfield@mmu.ac.uk), Judith Rodwell (Judith.rodwell@mmu.ac.uk), Laura Curry (1.curry@mmu.ac.uk), and Gillian Marks (g.marks@mmu.ac.uk)

Department of Psychology, Manchester Metropolitan University, UK

Corresponding author:

Dr. Jeremy Oldfield

Department of Psychology

Manchester Metropolitan University

Brooks Building

Birley Fields Campus

53 Bonsall Street,

Manchester,

M15 6GX

\section{Key words}

Attendance, University, Belonging, Lecture, Seminar 


\title{
A face in a sea of faces: exploring university students' reasons for non-attendance to teaching sessions.
}

\author{
Abstract \\ In the past twenty years, the landscape of Higher Education in the United Kingdom \\ has changed considerably. With the prospect of tuition fees spiralling above $£ 9,000$ per year, \\ per student, it is important to explore the impact this has upon the student experience. In spite \\ of the vast financial investment current students make toward their education, student \\ attendance and engagement remains low. The present study therefore adopted a qualitative \\ approach using focus groups to explore reasons for non-attendance at university teaching \\ sessions. Four key themes emerged; these surrounded issues about a sense of belonging to \\ university, views of the teaching (material taught and the personality and method of the \\ tutor), perceptions of being a consumer; and external pressures. This research suggests that \\ universities should pay particular attention to the reasons why students do not attend and \\ possibly change practice, providing more support where appropriate.
}




\section{Introduction}

\section{Current structure of Higher Education in the United Kingdom}

The landscape of Higher Education (HE) has changed significantly within recent years. Increasing tuition fees, neoliberal educational polices, and marketised universities have created a culture wherein HE has become a transactional exchange or a 'product a student purchases' (Feigenbaum and Iqani, 2015:47) at significant personal expense. Since 2012, students in England pay upwards of $£ 9,000$ per year in tuition fees alone, and have the highest average undergraduate tuition rates in the industrialised world (OECD, 2015). The impact of this will be felt most by low-income students who, with the removal of grants (HM Treasury 2015), will now leave university with debts of an estimated $£ 60,000$ (Wolff, 2015), even before they embarked on a career. This, alongside the marketization of HE, has turned students into customers and academics into service providers (Brady, 2012; Feigenbaum and Iqani, 2015). Molesworth et al. (2009: 277) further argue that 'market discourse promotes a mode of existence, where students seek to 'have a degree' rather than 'be learners',

Post-2012 students commonly view their education as a reciprocal relationship, whereby they acknowledged the importance of making an investment of their time, effort, and money, with the goal of achieving career and economic security in later life (Tomlinson, 2016). Nonetheless, there often remains a low level of student engagement and high levels of non-attendance at universities (Mearman, Pacheco, Webber, Ivlevs, and Rahman, 2014; Marburger, 2006). This has led to the implementation of attendance monitoring systems at many universities (Macfarlane, 2013). Furthermore, research has investigated the reasons why students are not attending lectures and seminars despite the considerable amount of time and money they are investing in their education (Oldfield, Curry, Rodwell and Marks, 2016).

\section{Attendance and Retention}


Students with poor attendance records are more likely to drop out of their university courses (Beggs and Smith, 2002). This can result in serious financial implications for themselves (Student Finance England, 2016), as well as for their institution (Bowen et al., 2005; Prescott and Simpson, 2004). Thomas (2012) calculated that a non-residential student who leaves university before completion equates to a loss of income totalling $£ 24,300$. The advantages of completing an undergraduate degree however, extend beyond financial benefits. Graduates often have greater social mobility, longer life expectancy, better mental and general health, are less likely to commit crime, and have greater life satisfaction (Department for Business, Innovation and Skills, 2013). Arguably, these non-market benefits will be lost if students prematurely withdraw from their course at university (Thomas, 2012).

Research investigating non-attendance at university teaching sessions has therefore been extensive (e.g. Friedman, Rodriguez and McComb, 2001; Gump, 2004; Marburger, 2006; Dolnicar, Kaiser, Matus and Vialle, 2009; Mearman et al., 2014). Nonetheless, questions remain how best to predict non-attendance and therefore how best to combat nonengagement within the changing climate of increased university fees.

Macfarlane (2013) evaluated engagement-monitoring systems at universities that have been utilised to promote attendance. The findings showed that when attendance was monitored it enhanced student accountability, ensured they were more prepared for the course content and made them accountable in terms of their social environment within their peer group. Nonetheless, despite a legal requirement at UK universities to monitor attendance, it does little to benefit the learning experience and removes the independent engagement required to become an active learner. 


\section{Belonging}

A salient theme within the literature that could partly explain reasons for nonattendance is the concept of belonging (Oldfield et al. 2016). From a psychological perspective, belonging is presented as being a subjective feeling linked to a basic and pervasive motivational drive (Baumeister and Leary, 1995). This research proposed that the need for belonging is a fundamental motivation to seek out and to form a secure interpersonal attachment. Failure to satisfy this need may negatively affect a student's health, well-being and cognitive processes, and this might be linked to engagement and attendance at teaching sessions.

Research has shown across a range of contexts, that belonging is a key aspect of attendance, student retention, and academic success within the UK (Thomas, 2012), US (O’Keeffe, 2013) and the Netherlands (Meeuwisse, Severins and Born, 2010). For example, Thomas (2012) found that despite a significant minority of students (between 37-42\%) considering leaving HE during their first year at university, those who do not withdraw from their course tend to have a better understanding of their university and a positive relationship with peers and staff. Reasons given by those who did consider withdrawal included feeling isolated and not having built good relationships.

The quality of the interpersonal relationships students experience is therefore important in forming a positive sense of belonging (Mellor, Stokes, Firth, Hayashi, and Cummins 2008). The nature of this interpersonal relationship can affect student motivation (Bennett, 2003) and their ability to benefit from learning opportunities (Levett-Jones and Lathlean, 2008), which may be reflected in their attendance.

\section{Predictors of non-attendance}


Class size has been reported to influence attendance as students are more likely to be absent from larger classes such as lectures (Friedman et al., 2001) due to an increased feeling of anonymity as they do not feel able to contribute (Keen, 2006). This is not only problematic at an institutional level, but in terms of student experience, and academic performance (Bandiera, Larcinese and Rasul 2010). Feigenbaum and Iqani (2015) argue that large class sizes make it difficult for lecturers to know students and provide 'continuity of care' (2015:52). Nonetheless, Exeter, Ameratunga, Ratima, Morton, Dickson, Hsu, and Jackson (2010) explored teachers views of larger class sizes, and concluded that using some teaching methods often adopted in smaller group settings, for example, group discussion and problembased learning, could work well in larger lectures.

A great deal of the research into attendance and engagement at university has been premised on a fairly narrow definition of a 'typical' or traditional university student. Thomas, (2015) describes the 'typical' student as being 'full-time, young, time-rich and at least initially resident on campus' (pp38). However, it is often the non-typical student, such as the mature students who do not live on campus, who are more likely to disengage, have poorer attendance and subsequently leave the course, as they do not feel they are receiving adequate support from their institution (Laing and Robinson, 2003). It is important therefore to look beyond the stereotype of a 'typical' university student and include a more diverse group in any subsequent research. Barrow (2008) argues that our definition and assumptions of traditional and non-traditional students are unhelpful in today's HE landscape considering our continually diversifying student population.

Unlike previous generations before, many current university students are no longer able to focus on their degree full time, as they have a necessity for part time work and other commitments outside of their course. The rise in tuition fees and reduction in grants has led to $77 \%$ of students in the UK needing to augment their loans with part-time employment 
(NUS/Endsleigh, 2015), which, can negatively influence attendance (Paisey and Paisey, 2004). Bennett (2003) found that experiencing financial hardship played a significant part in a students' decision to withdraw from their university course. Employment is likely to influence attendance at university although the evidence into its impact is mixed. Paisey and Paisey (2004) found that part time work commitments were one of most salient reasons why students miss classes, although in contrast, Morgan, (2001) found that work commitments had little impact on attendance. Research beyond the 2012 fee increase is however limited, nonetheless, Groves et al. (2015) and Kaye and Bates (2016) have argued that students are now more career focused, and view their degree and their debt as an essential means to employment and a career.

\section{Research aims}

Much of the research into student performance and retention has been conducted in the US (Credé, Roch and Kieszczynka, 2010; Gump, 2006; Marburger, 2006), where differences in academic and social structures could mean that this evidence may not easily translate into an explanation of the student experience in the UK. Furthermore, a considerable amount of this research linking sense of belonging to academic experience and attendance has involved school aged rather than university students (Freeman, Anderman and Jensen, 2007 and Goodenow, 1993). As such, there is a clear argument here for further research based in the UK, with a university population that includes non-traditional students. The aims of the current piece of research were to investigate traditional and non-traditional students' declared reasons for non-attendance at university teaching sessions using an in-depth qualitative methodology and analysis.

\section{Methodology}




\section{Overview}

The aim of this study was to explore students' declared reasons for non-attendance at university teaching sessions. The research team adopted a qualitative approach, employing a focus group methodology. Focus groups provided students with the opportunity to share their thoughts and feelings with their peers and to discuss personal experiences (Barbour, 2007). This method allows a group consensus to emerge for a shared experience such as attendance at teaching sessions (Stewart, Shamdasani, and Rook, 2007). Each focus group lasted between 60 and 90 minutes in order to avoid participant fatigue yet retain an informative level of discussion and to facilitate the production of useful data (Liamputtong, 2011). Discussions were transcribed and analysed using thematic analysis (Braun and Clarke, 2006).

\section{Participants}

Participants were recruited from the Department of Psychology at a university in the North West of England. Thirty-six participants comprising $n=15$ first year students and $n=$ 21 second year students took part in the research. Participants were representative of the student cohort, comprising of both males and females of various ages and ethnic backgrounds. Participants were recruited from the undergraduate psychology cohort via emails sent to their university accounts or invitations within teaching sessions. Eight focus groups were conducted with group sizes ranging from two to six individuals. Group sizes of six were deemed the optimal number to allow for sufficient depth and detailed contributions by each participant. Groups less than six were only formed if participants did not attend the scheduled session they had signed up for. Smaller focus groups are able to generate rich discussion and are also easier to manage (Braun \& Clarke 2013). Participants received university 'Participation Pool' points for participating, which aids recruitment for their own dissertation project in the third year. All participants gave fully informed written consent 
before the conversations began. At the transcription stage of the interviews participants were allocated a pseudonym to ensure anonymity. The study gained ethical approval from the University Ethics Committee (February 2015).

\section{Data Collection and Analysis}

The research team devised the focus group interview schedule collectively, including topics designed to allow students to discuss their personal and declared reasons for nonattendance at university teaching sessions. Key topics assumed to be related to reasons for non-attendance were gathered from an extensive literature review of the area and from informal conversations with staff and students as well as a quantitative study assessing reasons for non-attendance (Oldfield, Rodwell, Curry and Marks 2016). Example questions included "What factors affect your decision to attend a session?" and "Is there anything about your learning environment that affects your attendance?" These questions were used as a guide for the focus group facilitators as the focus was upon a student led discussion. In the majority of the focus groups students covered all expected topics with little prompting. When the focus groups reached a natural conclusion (i.e. all expected topics had been discussed and conversation had halted) participants were offered the opportunity to comment further on any issue they felt had not been raised. Focus group interviews were conducted within a familiar environment for the students, and were carried out by non-academic members of staff to enable participants to speak freely about why they did not attend teaching sessions. The nonacademic members of the research team transcribed the audio recordings, allocating pseudonyms and removing all information that might identify a particular unit or academic staff member to ensure anonymity. Transcripts were analysed using a thematic analysis informed by Braun and Clarke (2006). 


\section{Analysis and Discussion}

The thematic analysis revealed four major themes in relation to the reasons provided by students for non-attendance at lectures and seminars; 'Do I belong?' 'Who is my tutor and what am I learning? 'Do I have external pressures?' and 'Am I a consumer?' The quotes used to support these themes from the participants are illustrative of major points that were covered within the focus groups. Individuals are quoted in order to illustrate the theme discussed within the focus group in their own words.

\section{Do I belong?}

This very prominent theme became evident through discussion around the anonymity of being a student within a large cohort and the effect large teaching groups have on attendance. Most students felt they were unknown to staff, and this is reflected by Jane a second year student who mentioned '... you're like, faceless'. Furthermore, Sara a year one student stated: 'I've walked past some of my lecturers in the hallway, like in the building, ... obviously they don't who I am or, so I guess it just makes you feel like, oh, just a face in a sea offaces!' Students often concluded that tutors would not realise they had not attended and therefore there would be no repercussions: 'You feel like even if you're not there nobody is going to notice. You're just faceless to the lecturers. They're not going to know if you're there or not.' (Alice, $2^{\text {nd }}$ year). Furthermore, Muiz a second-year student mentioned '... at college ... it was a smaller classroom size ... so if you didn't come in then the tutor could notice if you weren't in. With lectures, if you don't come in it won't be noticed.'

Mellor et al. (2008) state that a lack of communication between staff and students, due to the increase in student numbers, might lead to a lower sense of belonging due to a reduced level of supportive interaction with academic staff. This view was reflected within the present study when discussing the cohort size specifically, as students felt this had a profound effect 
on their ability to contribute in sessions, as well as feeling this contributed to their loss of identity and poorer attendance. For example, Alice a second-year student said 'You know like when you're in smaller groups like in the seminars, like, six people are there sometimes so you feel more comfortable talking and you feel more engaged ... you're more likely to go in. '. Sarah a year one student added 'Just-it's not as personal as I thought it was going to be. The seminars are really big. ... so you don't really feel like- you can't get to know the tutor.'

The statements related to the size of the classes support findings by both Friedman et al. (2001) and Keen (2006) who acknowledged that class size influences students as they feel anonymous and are more likely to miss a session where they are part of a larger group. Nonetheless, some students noted differences in the effects of class size as they transitioned through the degree course, 'It's more personal now. You can sit at a table and have a discussion with people about the topic.' (Muiz, $2^{\text {nd }}$ year). This could lead to the conclusion that cohort size affects attendance for first year students as they are less accustomed to the working practices of universities.

Smaller class sizes might aid engagement and attendance as several of the participants reported that seminars were preferable to lectures in terms of a feeling of belonging and being more able to contribute to the class. For example, one participant mentioned 'I prefer seminars to lectures, because ... (in lectures) there's so many people there and it's such a big room' (David, $1^{\text {st }}$ year). Furthermore, 'In the seminars or if people leave I'm more comfortable with that size because the classes from sixth form ... Whereas we have to put in extra effort to make sure that we stand out from everybody else.' (Sara, $1^{\text {st }}$ year).

These comments maintain Goodenow's (1993) evaluation of an ideal academic classroom setting, which should provide support and respect to enhance students' sense of feeling valued and encouraged by both the tutor and their peer group as it allows the 
interactions necessary to feel a sense of belonging, therefore providing a more positive experience on the course (Freeman et al. 2007). Some teaching sessions clearly provide this environment, as students did feel welcomed by the University and their tutors. For example, 'I like the feel of the University and the general-it's much more, a community' (Michaela, $1^{\text {st }}$ year) and 'I think, since I've been here it's been obvious that the lecturers do care more, I don't know if that's the same for all Universities or if this University is just brilliant.' (Janet, $1^{s t}$ year). What is evident from the data is that smaller class sizes would aid attendance.

\section{Who is my tutor and what am I learning?}

A second major theme that emerged from the data was 'Who is my tutor and what am I learning? This theme reflected issues concerning the content of material taught and the personality and method of the tutor.

Students reported that attendance to teaching sessions was related to whether the content was directly relevant to a piece of assessment. Participants described a notable increase in attendance when the sessions consisted of work related to an assignment, 'And now people have started to attend because we have an assignment coming up. That's probably why I attend.' (Roza, $2^{\text {nd }}$ year). When students had an approaching submission date in a different unit this impacted on their attendance as they were working elsewhere on their assignments 'If you go to a lecture when there's a deadline due, there's nobody in, whatsoever. And lecturers say like "oh, what's happened?" and we say "well, we've got a deadline due in."” (Phoebe, $2^{\text {nd }}$ year). Both lectures and seminars are perceived as uninformative unless providing information directly related to an assignment.

The tutor taking the session and the teaching methods used was an important factor affecting student attendance. If students did not feel the tutor was engaging or if the lecturer did not provide additional material beyond what was already available online, they were less 
likely to attend. The tutor leading the session was a particularly prominent factor for students in their decision to attend or not, with students being less likely to attend if they did not feel engaged by the tutor: 'I really enjoy seminars this year! But I think it's because of who I have' (Helen, $2^{\text {nd }}$ year). Quality of teaching is also reflected in the following quote 'When your lecturer is passionate about what they're teaching-and they make it interesting. That makes it good ... When you can see they're enjoying themselves and they like teaching you, they want to be here ...' (Alice, $2^{\text {nd }}$ year)

Teaching methods and approaches used by tutors also had a high impact on students' decisions to attend: 'You can tell by the way he teaches that he loves teaching. ... You just want to sit there and listen to him because he gives you all this extra information ... He'll go round and get people to talk, get them to write down their answers and be really encouraging.' (Safa, $2^{\text {nd }}$ year). Furthermore, tutors who adopt an approachable style and answer questions from students can also encourage attendance. This is reflected in the quote 'They carry you along, and it's so approachable, you know, you can talk to them and know that they're gonna answer your queries, they'll help you out.' (Monique, $1^{\text {st }}$ year). Dolnicar et al. (2009) did not find a link between the quality of the lecturer and attendance, however, there was a high correlation between the quality of the lecture content and delivery and student attendance. The present study findings support those by Friedman et al. (2001) who asked students for reasons that would encourage them to attend, and found that if the tutor was particularly engaging they would attend that class over one taught by another tutor. Additionally, they preferred to attend classes taught by tutors who made them feel valued when they attended.

\section{Do I have external pressures?}


In the focus groups, working to supplement student loans was a prominent topic: 'It's such a big thing like people can't afford not to work but it affects their uni. I suppose it's part of uni life.' (Olivia, $1^{\text {st }}$ year). 'For my accommodation I pay almost 2 grand per term. And you only get two grand and a half so if you're a student here you definitely need to work ... I think about it on a daily basis.' (Roza $2^{\text {nd }}$ year). Students are clearly aware of the cost of their education, but also in terms of their day-to-day expenses:

I had to choose a casual job ... so they'll text you saying "can you work this shift?” ... For the next couple of weeks I'd like to say no! Which isn't ideal because ... I need, I need the money to live. And then I end up missing uni to work to pay the bills and things like that. (Phoebe, $2^{\text {nd }}$ year).

It is clear from the quotations within this theme that students are less likely to be able to focus on their degree full-time if they have other demands in their lives that they need to balance (Barrow, 2008) and therefore need to be more selective with the sessions they choose to attend. It is known that many students need to work in order to fund their living costs (NUS/Endsleigh, 2015) however, the impact of this is still under-researched.

Due to the increase in tuition fees, many more students need to take out large loans, increasing their level of debt on graduation (Bolton, 2015; Wolff, 2015) as well as considering part-time employment to supplement their loan. This is likely to be an area requiring further research to clarify the effect of employment on attendance, and recent literature has highlighted that students are now more career focused and see their debt as a means to a career (Groves et al., 2015; Kaye and Bates, 2016) but the wider impact of that debt is important to consider.

The present study has contributed further information to the understanding of the nontraditional student in terms of the higher fee regime and additional pressures now faced by 
students. Paisey and Paisey (2004) found a negative effect on attendance for students who worked part-time, and Devadoss and Foltz (1996) linked poorer academic performance with financial stress and working alongside studying. The quotes from the present qualitative study provide an updated view of stresses and hardships currently encountered by students.

Other attendance-impacting factors mentioned by students included personal issues such as feeling homesick, and the stress associated with finding work experience related to the course: 'I think personal reasons impact- ... Suppose if you're homesick or got like personal stuff going on. Sometimes things don't hit you until you're actually on your own.' (Alice, $2^{\text {nd }}$ year). 'They're like "you need to volunteer, you need work experience, you need this, you need that" and you're like ... This is my timetable for uni, then I have all this uni work to do ...' (Jane, $2^{\text {nd }}$ year)

These statements suggest that pressures that are external to the course can influence the student experience. The present study supports Thomas (2015) who proposed that universities should create better support strategies for students. Thomas was referring to nontraditional students, however, the present study suggests that this approach should encompass both traditional and non-traditional students, many of whom have varying commitments outside their course.

\section{Am I a consumer?}

In terms of the perceived value of attending sessions, students felt that in some lectures tutors merely read off the lecture slides and did not add additional information. This reinforced their belief that the material can be read online at another time and therefore they did not need to attend: '... if you decided to only read lecture slides in your own time you could still pass your degree.' (Michaela, $1^{\text {st }}$ year) and 'When the lecturer just reads off the slides ... it makes me think that I could just do it at home so there's no point coming in.' 
(Bhav, $1^{\text {st }}$ year). These points may link to students viewing teaching as a service they are paying for (Feigenbaum and Iqani, 2015), and to findings that students are adopting an increasingly consumerist discourse which permits them to evaluate the 'service' they receive (Tomlinson, 2016). For example, in the present study, students stated that they perceive their course as a service they pay for, therefore they feel they can choose whether or not to attend 'But I do think it's good it's [attendance] monitored. But then again it's your own independent learning, innit? So it's up to you if you want to go to uni or not. You're paying your money.' (Sarah, $1^{\text {st }}$ year). This view is often further justified when comparisons are made with friends who do not attend 'Like when I miss it I feel bad and stuff, and then I think, well I haven't seen that certain person for about two months now, and ... they're still doing alright.' (Katrina, $2^{\text {nd }}$ year).

Yeah, one of my friends, he hasn't been since before Christmas. He's still getting, 60, 70 per cent every time so, it kinda does show them. And it's, just showing like you don't really need to come in ... everything's on Moodle. (Claire, $2^{\text {nd }}$ year).

This suggests that there is a general feeling amongst students that attendance is not a priority due to the availability of materials online, which supports Grabe et al.'s (2005) finding that students may actively use online resources to the detriment of their attendance. In the current study this appeared to be compounded by a comparison of their own attendance level to that of other students, and the perceived value gained from attending.

If it is the case that university courses are viewed as a product that students pay for (Feigenbaum and Iqani, 2015) they will be more likely to make decisions not to attend, however this non-attendance may affect their interpersonal relationships with their peers and tutors and may have a negative impact on their learning (Levett-Jones and Lathlean, 2008). 
As the current study has shown, students compare their own attendance to that of their peers, which may have an effect on those relationships.

\section{Limitations and Future Research}

A significant limitation of this study concerns the possibility the very students who do not attend teaching sessions also did not participate within this research. Attempts were made to recruit these hard to reach students from emails sent to their university accounts rather than just advertisements in teaching sessions. Furthermore, participants were informed that the research was being conducted by non-academic staff in order to reduce perceived negative outcomes for expressing views of non-attendance. This research could be criticised for lacking depth in the data as it utilised a focus group methodology and not individual interviews. Nonetheless, a focus group methodology was chosen to increase participation and allow more general discussion of opinions.

Although the aim of this study was to explore experiences from students studying psychology in further research the sample could be widened by involving students from different disciplines, more universities and a wider geographical area. This study focused on undergraduate students, and it would be interesting to compare the reasons for attendance or non-attendance in postgraduate students who are a group of students growing in number in HE. It would also be interesting to explore these issues from the point of view of tutors and support staff, as they are the people students interact with day-to-day when forming their sense of belonging and their evaluation of the University: they are the other half of that relationship and it is likely that their experiences and perceptions will influence it. 
The present study demonstrated that students in large groups often feel faceless and can therefore get away with missing classes due to number of students within their classes. To further explore this theme it would be interesting to follow the example by Macfarlane (2013) and explore the reasons why students should attend classes. Particularly when content is usually available online. This would ultimately lead to further discussion about the purpose of lectures and teaching at university, which could feed into future practice.

\section{Conclusion}

Students' feelings towards their attendance have been reflected in their sense of belonging, their views of the teaching and the fees they are paying, as well as their external pressures. The increase in student numbers has led to an atmosphere of anonymity, whilst the increase in fees has challenged the historical student-tutor relationship. Students, who increasingly see themselves as consumers, now take a more critical approach and evaluate their university experience against their expectation of what they might expect for the price they pay.

An important part of what universities provide in terms of delivery happens in the classroom and yet universities continue to experience low levels of attendance, suggesting that students, paradoxically, are not taking full advantage of the teaching and support that their university provides. Therefore, attendance monitoring is likely to become much more prominent (Macfarlane, 2013). This is perhaps only part of the answer, as universities must pay attention to the way in which they engage students with their course, and enable and motivate them to take full advantage of all that they offer. Whilst at the same time cultivating a sense of belonging in their students from the time they accept a place at the university and throughout their course. 
Thomas (2012) suggests that students often do not know how to access support when needed, so universities need to promote their support systems more forcefully i.e. counselling, and learning support. In terms of new strategies, the use of peer mentors may benefit students through receiving advice and guidance from course peers whilst also providing valuable employment and work experience for the mentors themselves. An Australian University trialled the use of peer mentors as 'Student Rovers', and found a particular advantage in their ability to engage students by supporting them as colleagues with a similar level of knowledge, thus improving their sense of belonging (Tout, Pancini and McCormack, 2013).

The present study has achieved its aim to provide a detailed insight into the reasons why students choose not to attend classes at university, and in doing so has revealed that the reasons are often complex and solutions need to be considered at both an individual and a university level. 


\section{References}

Bandiera, O., V. Larcinese, and I. Rasul. 2010. "Heterogeneous Class Size Effects: New Evidence from a Panel of University Students." The Economic Journal, 120: 13651398. doi: $10.1111 / \mathrm{j} .1468-0297.2010 .02364 X$

Barbour, R. 2007. Doing Focus Groups. London: Sage.

Barrow, C. 2008. "When 'non-traditional' is the norm: a new set of challenges." http://www.lancaster.ac.uk/fss/events/hecu5/docs/Papers/Barrow,\%20Charlotte.doc

Baumeister, R.F. and M.R. Leary. 1995. "The need to belong: Desire for interpersonal attachments as a fundamental human motivation." Psychological Bulletin 117:497529. doi: 10.1037/0033-2909.117.3.497

Beggs, B.J. and E. Smith. 2002. “Optimally maximising student retention in higher education." Paper presented to the Society for Research in Higher Education Annual Conference, Glasgow, December.

Bennett, R. 2003. "Determinants of Undergraduate Student Drop Out Rates in a University Business Studies Department.” Journal of Further and Higher Education 27 (2): 123-141. doi: 10.1080/030987703200065154

Bolton, P. 2015. "Student loan statistics: Briefing Paper.” No. 1079. London: House of Commons Library.

Bowen, E., T. Price, S. Lloyd and S. Thomas. 2005. "Improving the Quantity and Quality of Attendance Data to Enhance Student Retention.” Journal of Further and Higher Education 29:375-385. doi: 10.1080/03098770500353714 
Brady, N. 2012. 'From 'moral loss' to 'moral reconstruction'? A critique of ethical perspectives on challenging the neoliberal hegemony in UK universities in the $21^{\text {st }}$ century." Oxford Review of Education, 38 (3): 343-355. doi: $10.1080 / 03054985.2012 .698987$

Braun, V. and V. Clarke. 2013. "Successful qualitative research.” London: Sage.

Braun, V. and V. Clarke. 2006. "Using thematic analysis in psychology." Qualitative Research in Psychology 3(2):77-101.

Credé, M., S. G. Roch and U. M. Kieszczynka. 2010. "Class Attendance in College: A MetaAnalytic Review of the Relationship of Class Attendance with Grades and Student Characteristics" Review of Educational Research 80:272. DOI: $10.3102 / 0034654310362998$

Department for Business, Innovation and Skills. The benefits of higher education participation for individuals and society: key findings and reports "the quadrants". October 2013.

Devadoss, S. and J, Foltz. 1996. "Evaluation of Factors Influencing Student Class Attendance and Performance.” American Journal of Agricultural Economics. 78 (3): 499-507.

Dolnicar, S., S. Kaiser, K. Matus and W. Vialle. 2009. "Can Australian universities take measures to increase the lecture attendance of marketing students?" Journal of Marketing Education 31: 203-211. doi: 10.1177/0273475309345202

Exeter, D. J., S. Ameratunga, M. Ratima, S. Morton, M. Dickson, D. Hsu, and R. Jackson. 2010. "Student engagement in very large classes: the teachers' perspective". Studies In Higher Education 35 (7) 
Feigenbaum, A. and M. Iqani. 2015. "Quality after the cuts? Higher education practitioners' accounts of systemic challenges to teaching quality in times of 'austerity'." Journal of Further and Higher Education 39 (1):46-66

Freeman, T. M., L. H. Anderman and J. M. Jensen. 2007. "Sense of Belonging in College Freshmen at the Classroom and Campus Levels." The Journal of Experimental Education 75 (3):203-220. http://www.jstor.org/stable/20157456

Friedman, P., F. Rodriguez, and J. McComb. 2001. "Why students do and do not attend classes: Myths and realities." College Teaching 49(4):124-134.

Goodenow, C. 1993. "Classroom belonging among early adolescent students: relationships to motivation and achievement." Journal of early adolescence 13(1):21-43.

Grabe, M., K. Christopherson and J. Douglas. 2005. "Providing Introductory Psychology Students Access to Online Lecture Notes: The Relationship of Note Use to Performance and Class Attendance.” Journal of Educational Technology Systems 33(3):295-308

Groves, M., Sellars, C., Smith, J., and Barber, A. 2015. "Factors affecting student engagement: a case study examining two cohorts of students attending a post-1992 university in the United Kingdom." International Journal of Higher Education 4 (2): $27-37$

Gump, S. E. 2004. "The truth behind truancy: student rationales for cutting class." Educational Research Quarterly 28(2):50-58.

HM Treasury. 2015. Spending review and autumn statement. Cm 9162, London: HMSO. 
Laing, C. and A. Robinson. 2003. "The Withdrawal of Non-traditional Students: Developing an explanatory model." Journal of Further and Higher Education 27(2):175-185. doi: $10.1080 / 0309877032000065190$

Kaye, L. K. and E. A. Bates. 2016. "The impact of higher fees on psychology students' reasons for attending university." Journal of Further and Higher Education 2016:114.

Keen, T. L. (2006). What are the perceptions of lecturers and students as to the place of the mass lecture in undergraduate education courses. Unpublished honours thesis, University of Wollongong, New South Wales, Australia.

Kelly, K.M. 2001. Individual differences in reactions to rejection. In: Leary, M.R. (ed.) Interpersonal Rejection. New York: Oxford University Press, pp. 291-315.

Laing, C. and A. Robinson (2003) "The withdrawal of non-traditional students: developing an explanatory model." Journal of Further and Higher Education 27(2):175-185

Landin, M. and J. Pérez. 2015. "Class attendance and academic achievement of pharmacy students in a European University." Currents in Pharmacy Teaching and Learning 7(1):78-83. doi:10.1016/j.cptl.2014.09.013

Leathwood, C. and P. O'Connell. 2003. “'It's a struggle': the construction of the 'new student' in higher education.” Journal of Education Policy 18(6):597-615. DOI:10.1080/0268093032000145863

Levett-Jones, T. and J. Lathlean. 2008. 'Belongingness: A prerequisite for nursing students' clinical learning." Nurse Education in Practice 8(2):103-111. doi:10.1016/j.nepr.2007.04.003 
Liamputtong, P. 2011. Focus group methodology: Principles and practice. London: Sage.

Macfarlane, B. 2013. “The Surveillance of Learning: A Critical Analysis of University Attendance Policies." Higher Education Quarterly 67:358-373. doi: 10.1111/hequ. 12016

Marburger, D. 2006. “Absenteeism and Undergraduate Exam Performance.” Journal of Economic Education 32(2):99-109.

Mearman, A., G. Pacheco, D. Webber, A. Ivlevs and T. Rahman. 2014. "Understanding Student Attendance in Business Schools: an Exploratory Study.” International Review of Economics Education 17:120-136.

http://www.sciencedirect.com/science/article/pii/S1477388014000346

Meeuwisse, M., S. Severiens and M. Born. 2010. "Learning Environment, Interaction, Sense of Belonging and Study Success in Ethnically Diverse Student Groups.” Research in Higher Education 51:528-545.

Mellor, D., M. Stokes, L. Firth, Y. Hayashi and R. Cummins. 2008. "Need for belonging, relationship satisfaction, loneliness, and life satisfaction." Personality and Individual Differences 45:213-218. doi: 10.1016/j.paid.2008.03.020

Molesworth, M., Nixon, E., and Scullion, R. 2009. "Having, being and higher education: the marketisation of the university and the transformation of the student into consumer." Teaching in Higher Education, 14 (3): 277-287.

Morgan, P. G. 2001. "Why Aren't They Always There? An Analysis of Student NonAttendance at Lectures." Working Paper presented at the Business Education Support Team Annual Conference, 2001. 
NUS/Endsleigh Insurance Services Limited. 2015. "10th August 2015 - 77\% of students now work to fund studies.” Accessed 17th February, 2016 from https://www.endsleigh.co.uk/press-releases/10-august-2015/

O’Keeffe, P. 2013. “A Sense of Belonging: Improving Student Retention.” College Student Journal 47(4):605-613.

OECD. 2015. "Education at a glance 2015: OECD indicators." Unknown place of publication: OECD Publishing

Paisey, C. and N. Paisey. 2004. "Student Attendance in an Accounting Module - Reasons for Non-Attendance and the Effect on Academic Performance at a Scottish University." Accounting Education 13(1):39-53. DOI: 10.1080/0963928042000310788

Prescott, A. and E. Simpson. 2004. "Effective Student Motivation Commences With Resolving 'Dissatisfiers'.' Journal of Further and Higher Education 28:247-259. https://core.ac.uk/download/files/2/260681.pdf

Stewart, D.W., P. N. Shamdasani and D. W. Rook. 2007. Focus groups: Theory and practice, 2nd edition. Thousand Oaks, CA: Sage.

Student Finance England. 2016. Student loans - a guide to terms and conditions. Glasgow: Student Loans Company.

Thomas, L. (2012) Building student engagement and belonging at a time of change in higher education. London: Paul Hamlyn Foundation

Thomas, Kate. 2015. Rethinking Belonging Through Bourdieu, Diaspora and the Spatial. Widening Participation and Lifelong Learning, 17 (1): 37-49. 
Tomlinson, M. 2016. "Student perceptions of themselves as 'consumers' of higher education, British Journal of Sociology of Education, 2016, pp. 1-15.

Tout, D., G. Pancini, and R. McCormack. 2013. Using mobile peer mentors for student engagement: Student Rovers in the Learning Commons. Higher Education Research \& Development. 33:3, 595-609. DOI: 10.1080/07294360.2013.841645

Wolff, J. 2015. "A university funding system designed to crush the aspirations of the poor." The Guardian, 15th December.

http://www.theguardian.com/education/2015/dec/15/university-funding-crush-poorgrant?CMP=twt_gu 